\title{
Gorputza eta identitatearen eraikuntza Haur Hezkuntzako hezitzaileen ikuspegitik
}

\author{
Eider Goñi \\ Bilakaeraren eta Hezkuntzaren Psikologia \\ Hezkuntza eta Kirol Fakultatea (UPV/EHU) \\ eider.goni@ehu.eus \\ Iraide Donaire-Hidalgo \\ Haur Hezkuntzako irakaslea eta psikomotrizista \\ iraidedonaire@gmail.com \\ Amaia Alvarez-Uria \\ Hizkuntzaren eta Literaturaren Didaktika \\ Hezkuntza eta Kirol Fakultatea (UPV/EHU) \\ amaia.au@ehu.eus
}

DOI: http://dx.doi.org/10.1387/tantak.19826

GAKO-HITZAK: Haur Hezkuntza, gorputza, lanketa, genero identitatea, hezkidetza.

\section{SARRERA}

Identitatearen eraikuntza prozesu konplexua da duda gabe eta psikologiatik horren eraikuntza soziala zein pertsonala azaltzeko saiakerak egin dira. Hori bai, Xx. mendeko bigarren erdian psikologiaren kognitibizazio arrazionalistak bigarren plano batera eraman zituen identitatearen arlo emozionala eta korporala (Botella, Grañó, Gámiz eta Abey, 2006). Azken urteetan mahai gainean jarri dira prozesu horiek eta baita eraikuntza prozesuaren izaera jarraitua: identitatea ez da produktu bukatua, baizik eta harreman, diskurtso eta dialektika aldakorren emaitza.

Gorputz erlazionalaren ideia da Merleau-Pontyk dioen hurrengoa: gorputza gizakiak munduan zehar ibiltzeko duen garraiobidea dela, eta gorputza eta mundua banaezinak diren neurrian, norbanakoak munduaren bitartez gorputzaren kontzientzia hartzen duela eta aldi berean, gorputzaren bitartez munduaren inguruko kontzientzia garatzen duela (Merleau-Ponty, 1999, 
122 orr.). Psikologia klasikoaren ikuspegiak, aldiz, gorputza objektu bezala hartzen du (Voen Doellinger, 2011). Beraz, gorputzaren inguruan pentsatu eta idatzi dutenak objektibaziotik kontzeptzio dinamikoago batera pasa dira.

Gorputza ez da munduan dagoen beste objektu bat, eta subjektua bakarrik ere ez; norbanakoak duen komunikabidea da (munduarekin harremanetan jartzen duena) eta gertu dagoen zerbait, eskueran, baina inoiz ez benetan beraren aurrean dagoena (Merleau-Ponty, 1999, 207 or. ). Norbanakoak duen norberaren gorputzaren pertzepzioa, beraz, ez da zuzena, baizik eta gorputz-eskema deritzonaren bitarteko honako hau: gorputzak mundu sentsorialean duen jarreraren kontzientzia hartzea da, non organo eta atal desberdinak dauden integratuta (Merleau-Ponty, 1999, 145 orr.). Gure gorputzaz, gorputz-zatiez, mugimenduaz eta mugez osatzen dugun irudikapen horri esker gure gorputza ezagutzen dugu eta gure helburuetara egokitu dezakegu (Palacios eta Hidalgo, 1999).

Schilder-ek (1999) horrekin lotura duen baina desberdina den kontzeptu bat definitu zuen: gorputz-irudia norbanakoak bere gorputzari buruz eraikitzen duen irudikapena da, esperientzia anitzetan eraikitzen dena (sinestesikoak, laberintikoak, ukimenezkoak eta, bereziki, bisualak); ingurunea ulertzeko eta koordinazio motore asegarri baterako beharrezkoa den osotasuna da (Tisserson, 1995). Baina pertzepzio eta irudikapen hutsak gainditzen ditu. Bi dira gorputz-irudiaren funtzio nagusiak: alde batetik, gorputz-atalen eta gorputz osotasunaren arteko erlazio dinamikoa ezagutzea eta, beste aldetik, gorputz-atal bakoitzak jarduera zehatz batekin lotzen baimentzea (Pankow, 1981).

Oso gertu dauden bi kontzeptu dira, baina plano desberdinetan agertzen dira. Gorputz-irudia norberaren historiari hertsiki lotuta dago, inkontzientea da eta egungo harreman sozialetan isla dauka (Dolto, 1984, 21 orr.). Gorputz-eskema, ordea, pre-kontzientea eta kontzientea da funtsean, errealitate bat da eta organismoaren integritatearen menpekoa da (Tisserson, 1997); harremanen objektibazioa baimentzen du.

Beste hitz batzuekin esanda, gorputz-eskema bulkada edota desioen iturri den bitartean, gorputz-irudia esperientzia sozioemozionalak sintetizatzen diren lekua da, besteekin ditugun harremanen emaitza da. Gorputzaren irudia pertsonak bere gorputza bizi eta sentitzeko duen modu sinbolikoa da eta beraren antolakuntzan hitzek, hizkuntzak hortaz, laguntzen dute.

Hizkuntzari esker umeari besteekiko harremanen mundua irekitzen zaio. Hartu-emanetan, gorputzak besteak topatzea ahalbidetzen digu, indibidualtasuna baieztatzen duen bitartean, gorputzean desirak, sentsazioak eta emozioak jaio eta adierazten direlako (Parisoli, 2002). Hau da, gorputzak munduan egoteko modu bakarra eta propioa errazten badigu ere, besteekin kontaktuan egoteko bidea da aldi berean; munduarekin dagoen kontaktu jarraian oroitzapenak pilatzen doaz, gorputza fenomeno historiko bihurtuz eta identitate pertsonalaren sentimendua eraikiz (Ribeiro, 2003). Garapen sozio-pertsonalaren oinarria da, azken batean. 
Gorputz hori azalak janzten du, aldi berean izakia mugatzen duena eta izakia besteekin zein munduarekin harremanetan jartzen duena. Hortaz, azalak norbanakoaren identitate sentimenduan rol garrantzitsua dauka (Von Doellinger, 2011). Bereziki garrantzitsua da azalak identitatearen osaeran jokatzen duen papera jaioberrien kasuan (Bick, 1991) eta garapenaren fase goiztiarretan; «ni-azala» terminoarekin ulertzen dugu haurrak bere buruaz egiten duen irudikapena beraren gorputz-azaleko esperientzietatik abiatutakoa dela, paralelismo bat eratzen delarik azalaren eta «ni»aren funtzioen artean (Anzieu, 2003, 50-51 orr.). Baina azalak duen funtzio hori bizitzan zehar berdin mantenduko ote da? Oro har, haurtzaroan gorputzaren presentzia nabaria dela adierazten dute ondorengo lerroetan agertzen diren ideia hauek.

\section{NORBERAREN EZAGUTZAREN GARAPENA}

Norberaren ezagutza jaiotzen garen bezain pronto garatzen doa, nahiz eta prozesua oso luzea den. Lehenengo bi urteetan ezin da esan umeek bere buruaz inolako ezagutzarik dutenik eta, gehienez, identitate existentzial bati buruz hitz egin ohi da, hau da, umeek ikasi beharreko lehendabiziko gauza besteekiko subjektu independenteak direla da (Mora eta Palacios, 1999). Are gehiago, jaioberriak ezin du onartu ama begi-bistaz galtzea, bere zati baten falta bezala sentitzen baitu.

«Ni»a kontzeptu bezala ez da egun batetik bestera eraikitzen eta, normalean, hiru etapa igarotzen dira guztiz osatu arte: lehenik nia ezagutzea, ondoren deskribapena eta, azkenik, autoebaluazioarekin lotutako erantzun emozionalak (Stipek, Gralinski eta Koop, 1990). Umeak bigarren urtean zehar bere burua ezagutzen du objektu bezala, beraz, hasiera batean ez du bere nortasunaren iraupenaren kontzientziarik; ondoren, hirugarren urtean, sinbolizazio-gaitasunarekin eta hizkuntzaren garapenarekin batera, kontzientzia hori agertu ohi da eta umea bere buruari ezaugarri zehatzak egozteko gai izaten hasten da. Edonola ere, erabateko kontzientzia geroago agertzen da, helduen erreakzioen ondorioz eta horren isla da umeak bere jokabidea ezkutatu nahi izatea edo gaizki jokatzea ekiditea besteek behatzen dutenean edo arreta deitzen diotenean (Hoffman, Paris eta Hall, 1995). Argi dago, orobat, norberaren ezagutzaren eraikuntza prozesu luze eta konplexua dela, hasteko eta behin, gaitasun kognitibo zehatzen menpe dagoena eta besteekiko harremanetan garatzen dela ere bai.

Ezagutza propioaren eraikuntzan umeak bere buruaz duen irudia ezaugarriekin aberasten doa eta horri autokontzeptua deritzo (Palacios eta Hidalgo, 1999). Horrela, ume batek altua, lodia, txintxoa eta azkarra dela esan dezake bere buruaren definizioa gero eta konplexuagoa garatu arte. Oso goizetik kanpo atributuen arabera umeak bere burua neska edo mutiltzat hartuko du (Benítez eta Fernández, 2010). Haur Hezkuntzako ume batek estereotipoen 
arabera bigarren mailako ezaugarri sexualak erabiliko ditu zerbait femenino edo maskulino bezala epaitzeko eta kanpo ezaugarri horiek alda daitezkeenez, sexu-identitatea aldakorra dela ulertuko du ere bai. «Sexuaren iraupena» ez da Haur Hezkuntzako etaparen bukaera arte (6-7 urte) heltzen.

Edozein kasutan, arinago edo geroago, umeak sexu-identitatea eratuko du neurri handi batean gorputzak ematen dion informazioari lotuta eta ez da bat-batean gertatzen den eraikuntza izango. Neurozientziarekin bat datorren konstruktibismo erlazionalaren ikuspegitik, self-aren gorputz-dimentsioaren eraikuntza pertsonalak barne hartzen ditu hainbat azpi-dimentsio (Cash eta Pruzinsky, 1990):

- 1. maila: gorputz-eskema, gorputza espazioan dagoen objektu bezala eta plazer edo min iturri bezala.

- 2. maila: body-self, nia eta ez-niaren arteko bereizketa eta korporalitatean zentratutako kontzeptu espazio-tenporalak.

- 3. maila: gorputza diskurtso bezala, dimentsio sinbolikoa eta analogikoa.

- 4. maila: gorputza kontzeptu bezala, esperientzia zuzenaz gain, kultura eta hezkuntzatik jasotako gorputzari buruzko nozioak.

Hortaz, self-aren eraikuntza hau hasierako garapen estadioko dimentsio sentsoriomotoretik autokontzientzia mailarik gorenera doa (Botella et al., 2008). Hori horrela bada, gorputzaren kontzientzia eta identitate sexualaren garapena haurtzaroan bukatzen ez dela argi geratzen da eta orain arte ezagutzen genituen «garapen-hitoak» erlatiboak direla pentsa dezakegu. Ondorioz, hezkuntza-sistemak araudian garapen arlo honi dagozkien helburuak, gaitasunak eta landu beharreko edukiak zeintzuk diren aztertu beharko da eta, behar izatekotan, zalantzan jarri ere bai.

\section{GORPUTZA ETA NORBERAREN EZAGUTZA CURRICULUMEAN}

Sexu-identitate eta generoaren eta hezkuntzaren arteko harremanari heltzeko beharra argia da. Gobernuek nazioarteko mailan generoari edota sexualitateari lotuta gertatzen diren bazterkeria egoerak gainditzeko konpromisoa erakutsi dute hainbatetan, Beijingo Deklarazioan (Nazio Batuen Erakundea, 1995) eta Milurteko Helburuetan (Nazio Batuen Erakundea, 2010), besteak beste.

Bazterketa egoerak ez dira desagertuko gizarteak gaiari buruz dituen irudikapenak aldatzen ez diren bitartean, bereziki irakasleek dituzten irudikapenak; haiek hezkuntza instituzioetan egoten diren bereizkeria, bazterketa eta bortizkeria legitimatu ditzaketelako (Quaresma Da Silva, Sarmento eta Fossati, 2012). Hala ere, hainbat ikerketak adierazi dutenez, nahiz eta heteronormatibitatea gainditzeko irakasleek prestakuntza beha- 
rrezkoa duten, erresistentziak eta zailtasunak ohikoak dira (Quaresma da Silva eta Ulloa, 2011; Silva eta Megid, 2006).

Bestalde, marko juridikoa alde edukitzea beste baldintza bat da, nahiz eta nahikoa ez izan. Hezkuntza praktika arautzen duten dokumentuetan ere identitatearen eraikuntzan gorputzak duen garrantzia argi geratzen da, bereziki Haur Hezkuntzako etapari dagozkion ataletan.

EAEko curriculumari helduz (236/2015eko Dekretua), oinarrizko/zehargaitasunen artean Norbera izaten ikasteko gaitasuna dugu, aurreko lege batzuetan izen horrekin zein beste batzuekin agertu izan ohi dena (1. irudia).

\begin{tabular}{|c|c|c|c|c|c|c|}
\hline \multirow[b]{2}{*}{ UNESCO } & \multirow[b]{2}{*}{$\begin{array}{c}\text { EUROPAR } \\
\text { BATASUNA }\end{array}$} & \multirow[b]{2}{*}{ LOE } & \multirow[b]{2}{*}{$\begin{array}{c}175 / 2007 \\
\text { DEKRETUA } \\
\text { (EAE) }\end{array}$} & \multirow[b]{2}{*}{$\begin{array}{c}\text { ED 126/2014 } \\
\text { (LOMCE) }\end{array}$} & \multicolumn{2}{|c|}{ HEZIBERRI 2020} \\
\hline & & & & & $\begin{array}{c}\text { Zehar- } \\
\text { konpetentziak }\end{array}$ & $\begin{array}{c}\text { Diziplina } \\
\text { baitako } \\
\text { konpetentziak }\end{array}$ \\
\hline $\begin{array}{l}\text { Ezagutzen } \\
\text { ikastea }\end{array}$ & $\begin{array}{l}\text { Ikasten } \\
\text { ikastea }\end{array}$ & $\begin{array}{l}\text { Ikasten } \\
\text { ikastea }\end{array}$ & $\begin{array}{l}\text { Ikasten ikasteko } \\
\text { konpetentzia }\end{array}$ & $\begin{array}{l}\text { Ikasten } \\
\text { ikastea }\end{array}$ & $\begin{array}{l}\text { Ikasten eta } \\
\text { pentsatzen } \\
\text { ikasteko } \\
\text { konpetentzia }\end{array}$ & \\
\hline $\begin{array}{l}\text { Egiten } \\
\text { ikastea }\end{array}$ & $\begin{array}{l}\text { Ekimena eta } \\
\text { ekintzaile- } \\
\text { espiritua }\end{array}$ & $\begin{array}{l}\text { Autonomia } \\
\text { eta gizarte- } \\
\text { ekimena }\end{array}$ & $\begin{array}{l}\text { Norberaren } \\
\text { autonomiarako } \\
\text { eta ekimenerako } \\
\text { konpetentzia }\end{array}$ & $\begin{array}{l}\text { Ekimena eta } \\
\text { ekintzaile- } \\
\text { espiritua }\end{array}$ & $\begin{array}{l}\text { Ekimenerako } \\
\text { eta pentsatzen } \\
\text { ikasteko } \\
\text { konpetentzia }\end{array}$ & \\
\hline $\begin{array}{l}\text { Elkarrekin } \\
\text { bizitzen } \\
\text { ikastea }\end{array}$ & $\begin{array}{l}\text { Konpetentzia } \\
\text { interpertsonal } \\
\text { a eta zibikoa }\end{array}$ & $\begin{array}{l}\text { Gizarterako } \\
\text { eta } \\
\text { herritartasune } \\
\text { rako } \\
\text { konpetentzia } \\
\end{array}$ & $\begin{array}{l}\text { Gizarterako eta } \\
\text { herritartasunerak } \\
\text { o konpetentzia }\end{array}$ & $\begin{array}{l}\text { Gizarterako } \\
\text { konpetentziak } \\
\text { eta } \\
\text { konpetentzia } \\
\text { zibikoak } \\
\end{array}$ & $\begin{array}{l}\text { Elkarbizitzarak } \\
\text { o konpetentzia }\end{array}$ & $\begin{array}{l}\text { Gizarterako eta } \\
\text { herritartasunerak } \\
\text { o konpetentzia }\end{array}$ \\
\hline $\begin{array}{l}\text { Izaten } \\
\text { ikastea }\end{array}$ & & $\begin{array}{l}\text { Autonomia } \\
\text { eta gizarte- } \\
\text { ekimena }\end{array}$ & $\begin{array}{l}\text { Norberaren } \\
\text { autonomiarako } \\
\text { eta ekimenerako } \\
\text { konpetentzia }\end{array}$ & & $\begin{array}{l}\text { Izaten ikasteko } \\
\text { konpetentzia }\end{array}$ & \\
\hline & $\begin{array}{l}\text { Ama } \\
\text { hizkuntza }\end{array}$ & \multirow{2}{*}{$\begin{array}{l}\text { Hizkuntza- } \\
\text { komunikazioa }\end{array}$} & \multirow{2}{*}{$\begin{array}{l}\text { Hizkuntza- } \\
\text { komunikaziorako } \\
\text { konpetentzia }\end{array}$} & \multirow{2}{*}{$\begin{array}{l}\text { Hizkuntza- } \\
\text { komunikazioa }\end{array}$} & \multirow{3}{*}{$\begin{array}{l}\text { Hitzez, hitzik } \\
\text { gabe eta modu } \\
\text { digitalean } \\
\text { komunikatzeko } \\
\text { konpetentzia }\end{array}$} & \multirow{2}{*}{$\begin{array}{l}\text { Hizkuntza- eta } \\
\text { Literatura } \\
\text { komunikaziorako } \\
\text { konpetentzia }\end{array}$} \\
\hline & $\begin{array}{l}\text { Atzerriko } \\
\text { hizkuntzak }\end{array}$ & & & & & \\
\hline & $\begin{array}{l}\text { Konpetentzia } \\
\text { digitala }\end{array}$ & $\begin{array}{l}\text { Informazioa } \\
\text { tratatzeko } \\
\text { konpetentzia } \\
\text { eta } \\
\text { konpetentzia } \\
\text { digitala } \\
\end{array}$ & $\begin{array}{l}\text { Informazioa } \\
\text { tratatzeko eta } \\
\text { teknologia } \\
\text { digitala } \\
\text { erabiltzeko } \\
\text { konpetentzia } \\
\end{array}$ & $\begin{array}{l}\text { Konpetentzia } \\
\text { digitala }\end{array}$ & & \\
\hline & \multirow{4}{*}{$\begin{array}{l}\text { Matematika, } \\
\text { Zientziak eta } \\
\text { Teknologia }\end{array}$} & \multirow{2}{*}{ Matematika } & \multirow{2}{*}{$\begin{array}{l}\text { Matematikarako } \\
\text { konpetentzia }\end{array}$} & \multirow{4}{*}{$\begin{array}{l}\text { Konpetentzia } \\
\text { matematikoa } \\
\text { eta } \\
\text { Zientziarako } \\
\text { eta } \\
\text { Teknologiarak } \\
\text { o } \\
\text { konpetentziak }\end{array}$} & & $\begin{array}{l}\text { Matematikarako } \\
\text { konpetentzia }\end{array}$ \\
\hline & & & & & & \multirow{2}{*}{$\begin{array}{l}\text { Zientziarako } \\
\text { konpetentzia }\end{array}$} \\
\hline & & \multirow{2}{*}{$\begin{array}{l}\text { Ingurune } \\
\text { fisikoaren } \\
\text { ezaguera }\end{array}$} & \multirow{2}{*}{$\begin{array}{l}\text { Zientzia-, } \\
\text { teknologia- eta } \\
\text { osasun- } \\
\text { kulturarako } \\
\text { konpetentzia }\end{array}$} & & & \\
\hline & & & & & & $\begin{array}{l}\text { Teknologiarako } \\
\text { konpetentzia }\end{array}$ \\
\hline & $\begin{array}{l}\text { Kultura-kon- } \\
\text { tzientzia eta } \\
\text { adierazpena }\end{array}$ & $\begin{array}{l}\text { Giza- eta arte- } \\
\text { kulturarako } \\
\text { konpetentzia }\end{array}$ & $\begin{array}{l}\text { Giza- eta arte- } \\
\text { kulturarako } \\
\text { konpetentzia }\end{array}$ & $\begin{array}{l}\text { Kultura-kon- } \\
\text { tzientzia eta } \\
\text { adierazpena }\end{array}$ & & $\begin{array}{l}\text { Arterako } \\
\text { konpetentzia }\end{array}$ \\
\hline
\end{tabular}

1. irudia

\section{Oinarrizko konpetentziak formulatzeko proposamen desberdinen arteko erkaketa}

Konpetentzia horren osagaien artean hauxe topatzen da: gorputzaren funtzioak eta norberaren osasuna, ongizatea, gorputz-irudia eta sexu-norta- 
suna autoerregulatzea. Ikasleen gorputz-irudia positiboa izango da onarpen prozesu bat egotekotan eta horren garrantzia agerikoa da umeak bere gorputzaren inguruko kontzientzia ez badu garatzen edo negatiboa bada (autokontzeptua negatiboa bada) autoestimua txikiagotuko da eta segurtasunik ezaren arriskua izango du.

Sexu-identitateari dagokionez, hurrengo termino hauetan hitz egiten da: «sexu-nortasuna zehazten dute emakumea, gizona edo sexuartekoa izatea dakarten ezaugarri biologikoen kontzientziak eta norberak sexualki gehien identifikatzen dituen ezaugarri psikologikoen kontzientziak» (237/2015eko Dekretua, 54 orr.). Hortaz, garrantzi betekoa da askotariko jarduerak diseinatzea eta gauzatzea ondoko helburu hauek lantzeko asmoz: nork bere burua zaintzea kalte fisikotik babesteko, gorputzaren zentzumen guztien bitartez esperimentatzeko plazera bilatzea, gorputzaren mugak eta ahalmenak ezagutzea eta onartzea, eta norberaren gorputzaren irudiarekin eta sexu-nortasunarekin pozik egotea.

Haur Hezkuntzako curriculumean ez da irakasgaiez hitz egiten, baizik eta esperientzia eremuez, besteak beste, Nortasunaren eraikuntza eta komunikazioa eta adierazpena eta Nortasunaren eraikuntza eta ingurune fisikoaren eta sozialaren ezaguera. Kasu bietan nortasunaren eraikuntza eta gorputza agertzen dira elementu nagusi bezala, azken finean, «gorputza, zentzumenak eta komunikatzeko eta adierazteko moduak erabiltzen ditugu ingurunearekin hartu-emanak izateko, eta horien bidez osatzen dugu gure eraikuntza pertsonala» (236/2015eko Dekretua, 9 orr.).

Umeek duten mundua ulertzeko moduak irakaskuntza-ikaskuntza prozesua baldintzatzen duenez, oso kontuan hartu behar dira euren ezaugarriak: a) Haur Hezkuntzako lehen zikloan (0-3 urte), gorputza da jolasean eta esperimentazioan martxan jarrita mundua arakatzeko eta esperientziak izateko abiapuntua eta espazioak-denborak, erritmo biologikoak eta plazera-mina izango dituzte erreferentzia; b) Haur Hezkuntzako bigarren zikloan (3-6 urte), hizkuntza garatu ahala, gorputza bigarren planora pasatzen da, baina oraindik ere bigarren esperientzia-eremuarekin lotutako egoeretan aparteko lekua izan ohi du: atsedena-erlaxazioa, loa, garbitasuna, elikadura, jolas sinbolikoa, etab.

Aurreko guztitik eratortzen dira Haur Hezkuntzako bi etapetarako Dekretuak zehaztutako helburuak. Hogeita bi helburuetako zerrendatik laubost erlazionatzen dira modu zuzenean nortasunaren eraikuntzan gorputzak duen paper protagonistarekin: norbera pertsona berezia dela ohartzea eta autokontzeptu orekatu eta positiboa osatzea, gorputza kontrolatzeko bidea urratzea, ongizateari dagozkion jarrerak lantzea, norberak dituen emozio eta sentimenduez jabetzea eta adieraztea, eta komunikazio-tresnak eskuratzea hartu-emanak interpretatzeko. Beraz, gorputzaren lanketa araudiak esplizituki jasotzen duen beharra eta eginbeharra bada, irakasleen ardura izango da nolakotasuna definitzea, hau da, zein metodologia eta baliabide erabiliko dituen zehaztea. 


\section{GORPUTZA ETA NORBERAREN EZAGUTZA LANTZEKO BALIABIDE DIDAKTIKOAK}

Haur Hezkuntzan gorputza eta identitatearen lanketa justifikatzen duen oinarri teoriko zein curricularra dagoela ikusi ondoren, galdera da ea horrek zer nolako isla duen materialen produkzioan.

Materialen errebisioa eginez gero (1. eranskina), gorputza eta identitatea lantzeko helburu duten ipuinak edota liburu anitz topa daitezke. Material gehienek adinari egokitutako antzeko edukiak (gorputz-atalak, neska-mutilen arteko diferentziak...) lantzen dituzte. Adibidez, HHko azken urteei erreparatuz, gehiago agertzen dira gorputzaren barneko organoak eta euren funtzionamendua.

Gaur egun, gero eta baliabide elektroniko gehiago topa daitezke edozein gairen lanketa egiteko proposamenekin. Gorputzaren inguruko lanproposamenak barnebiltzen dituzten blogak ere badira, baina normalean horiek ariketa solteak planteatzen dituzte (sekuentzia didaktikoren bat ere badagoen arren).

Bestalde, Nubaris dimentsioa izeneko proiektua (Ibaizabal, 2013a, b eta d) eta Urtxintxa proiektua (Batzuen artean, 2009a, b eta 2010) dira topatutako materialik osoenetarikoak, adin desberdinekin lan egiteko prestatuta daudelako eta curriculumeko gaitasun, helburu eta eduki guztiak lantzeko pentsatuta daudelako. Urte bakoitzeko materialetan topa daitezke unitate didaktikoak, zeinetan proiektuka lan egiteko metodologiari heltzeko aukera ematen den. Unitateez gain, badaude abestiak, ipuinak, horma-irudiak eta bestelako baliabide didaktikoak. Eusko Jaurlaritzak argitaratutako «Nor naiz ni?» proiektu zaharragoa (Eusko Jaurlaritza, 2003) bada gorputza eta identitatearen lanketarako material egokia ere bai.

\section{Helburuak}

Hori guztia kontuan, lan honetan Haur Hezkuntzan zein den generoaren presentzia eta irakasleek nola lantzen duten aztertzen da. Zehazkiago, generoaren gaiaren barruan gorputzak duen lekua aztertzeko helburuarekin, Haur Hezkuntzako hainbat hezitzailerekin, gurasoekin eta gaian adituak diren hezitzaileekin elkarrizketak eta eztabaida-taldeak garatu dira. Horren baitan, hurrengo azpi-helburuak zehaztu dira:

- Hezitzaileek gorputzari buruz dituzten irudikapenak ezagutzea.

- Haur Hezkuntzan gorputza, genero-identitateari lotuta, nola lantzen ari den identifikatzea.

- Binarismoa eta hereronormatibitatearekin bat egiten duten jarreren eta haiek gainditzeko posizioen inguruan hausnartzea.

- Haur Hezkuntzan erabilgarri dauden baliabide eta material didaktikoak errebisatu eta aztertzea. 


\section{Metodoa}

\section{Parte-hartzaileak}

Aukeratutako ikastetxeak perfil desberdinekoak dira, guztiak Gasteiz eta inguruko herrietakoak (ikus 1. taula). Ikastetxeei dagokienez, ezaugarri sozioekonomiko eta kultura anitzekoak dira, herri txiki, auzo zahar zein berrietan kokatutakoak, hain zuzen ere. Guztira bost elkarrizketa eta bost eztabaida-talde egin dira, guztiak 2015eko martxo-maiatza bitartean. Elkarrizketatuen adinari dagokionez, 25-55 urte bitartekoak izan dira, soslai anitzekoak eta gaian gehiago edo gutxiago adituak.

$$
\text { 1. taula }
$$

Elkarrizketa eta eztabaida taldeak burutu zireneko data eta kokapena, edota elkarrizketatuaren ezaugarriak

\begin{tabular}{|c|c|}
\hline Elkarrizketak & Eztabaida-taldeak \\
\hline $\begin{array}{l}\text { 2015/03/03 Gasteizko Berritzeguneko } \\
\text { berditasun arduraduna (ARD). }\end{array}$ & 2015/3/15 Gasteizko ikastola. \\
\hline $\begin{array}{l}2015 / 05 / 13 \text { Gasteizko erlijio-eskola ba- } \\
\text { teko pertsona trans baten irakaslea. }\end{array}$ & $\begin{array}{l}\text { 2015/04/16 Gasteizko Haurreskola } \\
\text { (auzo berria). }\end{array}$ \\
\hline $\begin{array}{l}\text { 2015/05/18 Hezkidetza plan berria du- } \\
\text { ten herri bateko irakaslea. }\end{array}$ & $\begin{array}{l}\text { 2015/05/19 Gasteizko udalerriko Haur- } \\
\text { eskola (auzo zaharra). }\end{array}$ \\
\hline $\begin{array}{l}\text { 2015/05/25 Herri bateko pertsona trans } \\
\text { baten irakaslea eta aita (FAM). }\end{array}$ & 2015/05/27 Gasteizko ikastola. \\
\hline $\begin{array}{l}\text { 2015/07/1 Gasteizko eskola publiko bat } \\
\text { (auzo zaharra eta kulturanitza). }\end{array}$ & $\begin{array}{l}\text { 2015/06/15 Gasteizko eskola publikoa } \\
\text { (auzo berria). }\end{array}$ \\
\hline
\end{tabular}

Lehenengoetarikoa Berritzeguneko berdintasun sailaren arduraduna izan da (ARD), hiriko eskola askorekin harremanetan dagoena eta hezkidetza materialen inguruan laguntza eta aholkularitza ematen diena. Horrekin batera, trans haur biren irakasleak (erlijio-eskola eta herri-eskolakoa), hezkidetza plana garatuta duen herri bateko eskolako irakaslea eta auzo zahar eta kulturanitzeko eskola bateko irakaslea (IRAK). Profesional horien lan ibilbidea aintzat hartuta, zentro desberdinetako errealitatearen azterketa diakroniko eta anitza egin da. Azkenik, transexuala den pertsona baten aita elkarrizketatu da (FAM), ikuspegia zabaltzeko asmoarekin. Azkenean, parte-hartzaileak 34 irakasle izan dira, lan ibilbide oso desberdinetakoak. Hau da, batzuk lan finkodunak eta beste batzuk urtero zentroz aldatu beharra dutenak.

Elkarrizketak eta eztabaida-taldeak Gasteizko Hezkuntza eta Kirol Fakultateko irakasle eta ikasleek dinamizatu dituzte (ELK). Haiek ordu ba- 
teko edota ordu eta erdiko iraupena izan dute. Une oro, beti, denbora guztian giro askea eta errespetuzkoa sortzen saiatu da. Beraz, elkarrizketatuek hezkidetzaren inguruko ideiak, pentsamenduak, sentimenduak askatasunez partekatzeko aukera izan dute, elkarrizketa dinamiko eta interaktibo baten bitartez. Hori guztia aintzat hartzeko, artikulua idazteko orduan anonimotasuna zaintzen saiatu izan da.

\section{Tresnak}

Lan hau egiteko metodologia kualitatiboa erabili da, elkarrizketatuak izan diren pertsonen diskurtsoetatik eta beraien jarreretan behatutakoetatik datu deskriptiboak sortzeko (Taylor y Bodgan, 1986). Ikerketa kualitatiboak testuinguru natural batetik errealitatea aztertzen du, behaketa, elkarrizketa eta beste metodoen bitartez (Lecompte, 1993). Azken batean, ikuspegi etnografikoa duen lana denez, gizarte unitate jakin baten bizitza estiloa deskribatzea eta interpretatzea du helburu. Gasteizko eta inguruko Haur Hezkuntzako ikastetxeetan genero identitateak duen ezagutza eta trataera norainokoa den aztertzea, hain zuzen ere; egoera deskribatu eta diagnostikatuz, gaur egun gai hau gizarteak nola hautematen duen argitzeko.

Hortaz, gaia aztertu ahal izateko elkarrizketa eta eztabaida-taldeak erabili dira: gaiaren inguruan informazio askotarikoa eskuratzeko nahiz informazioa sakon aztertu ahal izateko.

Elkarrizketa, informazioa lortzeko asmoarekin, elkarrizketatu baten eta elkarrizketagilearen artean egiten dena da (Juaristi, 2003). Beraz, pertsona biren artean egiten da. Halaber, konfiantza harremana sortu behar da, informazioa partekatzeko orduan elkarrizketatuak lasai, eroso eta naturaltasunez joka dezan. Alegia, teknika horren bidez elkarrizketatuarentzat garrantzitsua zer den jaso da. Hori horrela ez balitz, elkarrizketatuak informazio gutxi partekatuko luke eta gaian gutxiago sakonduko luke. Horregatik, aurretik aipatutakoak kontuan izan behar dira, elkarrizketak erabilgarriak izateko. Elkarrizketa era kontrolatuan egin da, aurretik prestatutako gidoi bat oinarri moduan erabili da. Abiapuntua hori izan arren, gidoia malgutasunez erabili da, hau da, ez da zurruntasunez erabili, elkarrizketaren norabidearen arabera moldatu da. Azken finean, egoera bakoitzera moldatuz. Elkarrizketa motei dagokienez, zuzendua eta holistikoa izan da; alde batetik, zuzendua, elkarrizketagileak gidoi bat oinarri izanda gidatzen duelako, baina malgutasuna ahaztu barik; bestetik, holistikoa, gai desberdinen inguruan hitz egin delako.

Eztabaida-taldea deritzo zerbait aztertzeko eta ezagutzeko pertsona bi baino gehiagok egiten duten eztabaidari (Juaristi, 2003). Kasu honetan, gai jakin bati buruzko ikuspegi eta iritziak ezagutzeko, talde bati egiten zaizkio galderak. Teknika honen bitartez, moderatzaile batek eta pertsona talde batek parte hatzen dute. Moderatzaileak, horren bidez, pertsona haientzat zer den garrantzitsuena ezagutzen du. Eztabaida-taldearen helburua gai baten 
arlo garrantzitsuenak ezagutzea, taldean egon ahal diren ikuspuntuak ikertu eta adostasunak eta desadostasunak aztertzea litzateke. Moderatzaileak taldearen eztabaida giroa kontrolatu du, pertsona guztien iritzien trukea ahalbidetuz eta giro lasaia bultzatuz. Eztabaidan atera diren ideiak, iritziak eta ikuspegiak aztertzea bilatu da.

\section{Analisiak eta prozedura}

Ikerketa-taldeak gaiari buruzko prestakuntza jaso ostean, gaiaren errebisio teorikoarekin hasi eta lanean aztertu nahi diren analisirako objektuak definitu ditu: irudikapen sozialak diren «gorputzaren ikaskuntza-irakaskuntza», «haurtzaroan gertatzen den genero identitatearen garapenean laguntza-prozesua» eta «hezkidetza, haren programak eta haien garapena». Idazki honetan aurkezten diren emaitzak lehen kategoriari dagozkionak dira, betiere beste biekiko harremanetan daudenak. Hauxe da, zehazkiago, erabili den kategoria-sistema:

- Gorputzaren ikaskuntza-irakaskuntza

- Definizioak

- Lanketa, metodologia

- Jarduerak

- Zeharkako lanketa

- Markoa, kokapena

- Ereduak, irudikapenak.

Elkarrizketen eta eztabaida-taldeen transkribapenak egin ostean, gorputzaren kategoriaren barruko azpi-kategoria sistemaren analisi lana egin da Nvivo 11 programaren laguntzaz; ondoren aurkezten dira emaitzak azpi-kategoriaka. Elkarrizketetako eta talde-eztabaidetako ahotsak emaitzetan jartzerako orduan, kodifikazio hauek erabili dira hitz egin duenaren arabera: elkarrizketagilea (ELK), irakasle elkarrizketatua (IRAK), elkarrizketa batean parte hartu duen pertsona transexual baten aita (FAM), Berritzeguneko genero arduraduna (ARD). Honez gain, bakoitzak zenbaki bat $\mathrm{du}$, pertsona bakoitza identifikatu ahal izateko eta elkarrizketa egin den data agertzen da. Ahotsetan izen batzuk agertzen dira, baina horiek ez dira errealak, honetarako asmatutako izenak dira.

\section{Emaitzak}

\section{Gorputzaren definizioa}

Gorputzari buruz maiz hitz egiten duten arren, irakasleek gorputza zer den ez dute argi adierazten. Eta badirudi ikerketa honetan ageri den datua 
izateaz aparte, Berritzeguneko kide batek aipatuta, irakasle gehienek ez dutela gorputza ezertarako aipatzen identitateari buruz galdetzen zaienean:

Irak1_15/03/03: Gure identitatea azaldu nahi dugunean, edo azaltzeko erabiltzen duguna, ez dugu batere lotzen gorputzarekin bere zentzu zabalean, batez ere emakumeen taldean... Gainera hor ez dago adinik... ze harreman arraro, por no decir harremanik ez, dugun emakumeok gorputzarekin. Eta hainbat gauzatan igual generazioak direla eta aldatu egin dira, baina gorputza hor dago pendiente...

Irakasleak, eta baliteke pertsonak orokorrean, ez dira euren gorputzarekin identifikatzen, identitatearen zati ez balitz bezala. Gorputzaren ezaugarri aipagarriena da ez dela hitzetan agertzen; hala ere, inplizituki, erraz kokatzen eta identifikatzen dute gaia eta ez dute horri buruz hitz egiteko arazorik.

\section{Lanketa eta metodologia}

Gorputzaren lanketan zentratu dira eztabaida-taldeak eta elkarrizketak gehienbat; egindako galderak eta jasotako erantzunak dikotomia batean koka ditzakegu: gorputzaren lanketa planifikatua egin ohi da edota egunerokotasunean sortzen diren egoeren bitartez lantzen da?

Unitate didaktikoak diseinatu eta erabiltzen dira? Badirudi ohitura zaharra dela unitateak erabiltzea, ariketak planifikatzea eta aurrera eramatea hainbat ekintza helburu jakinekin. Kasu honetan, diote, gai batean zentratzen dira:

Irak7_15/04/16: Planifikatutako ekintzetan hor azkenean hartzen duzunean gaia bat, zentratzen zara hor barruan, orduan bai ateratzen diozu, etekin gehixau (...) Gero klaro, hor dago hizkuntza ere bai, azkenean eurak badakite erderaz baina guk laguntzen diegu euskeraz ikasten, orduan horrekin bebai erlazionatzen dogu asko.

Modu horretan, ikasleek hizkuntza ere ikasten dute, hiztegi espezifikoagoa, alegia. Bestela, momentu oro erabiltzen diren gorputz-atalen izenak ikasteko ekintza espezifikorik ez dela behar diote, berez sortzen baita.

Espazio berezirik, txokorik, ez da prestatzen, berezko espazio natural ezin hobea baitago eskuragarri gorputzaren lanketa egiteko: komuna. Kasu honetan egunerokotasuneko ekintza batekin, gidatu gabe dagoena, lantzen da:

Irak7_15/04/16: Komuna modu inkontzientean lantzen dala, osea zu zara esto ba hartu papera garbitu alua, kaka egin duzu? Ba ipurdia garbituko dugu eta hori dana. Hori lantzen dozu bebai, baina hori, ez dago bideratuta, hori irtetzen da. 
Modu honetan gorputzaren lanketa biologiari hertsiki lotuta egiteko arriskua dago, hau da, ikuspegi binarista batetik, zeina sexu-genero sisteman oinarritzen den: genero identitatea ulertzen du dikotomikoki, hau da, edo emakumea edo gizona zara. Aniztasunaren ikuspegiak gorputza bizitzeko modu desberdinetara hurbilduko gintuzke, sistema binario murriztatzailea deseraikiz.

\subsection{JARDUERAK}

Gorputza lantzeko jarduera espezifikoak prestatzen dira beste edozein eduki lantzeko prestatzen diren bezala. Baina zer motatako jarduerak dira? Antza, siluetak erabiltzen dira askotan, gehienetan. Batzuetan, siluetak lantzen dira orokorrean:

Irak4_15/06/15: Saiatu ginen hasieran, bueno bakoitzari bere silueta egin geñun, ze atal dauzen, ba burua, besoa, hankak, baina dana orokorrean, ez dogu holan zehaztuta ez, ez dogu landu. dira:

Beste batzuetan sakontasun handiagoz, modu zehatzagoan landu ohi

Irak3_15/06/15: Atalak lantzeko, egun batean egin gendun, begiak koka, aurpegi bat hartu, zuri bat eta hori kokatu, aber begiak eta belarriak ea gai ziren kokatzeko eta jo orokorrean oso ondo, bi urte izateko pues gauza bakoitza ia bere lekuan jarri zuten. Bueno, aurretik landuta, aurretik landu genuen eta oso ondo, gustora.

Horrelako jarduera bati etekina ateratzeko aldez aurretik atalen izenak landuta izateak laguntzen du. Eta umeak aktibo dabiltza bakoitzaren silueta apaintzen, gero korridoreetan kokatzeko edota etxera eraman ahal izateko:

Irak3_15/06/15: Bakoitzaren siluetak egin genituen eta gero jarri genituen, gaude lau gela 3 urtekoak eta jarri genituen pasillo osotik, pasillo guztia siluetaz eta bakoitzaren aurpegia gero jarrita. Ta gero bakoitzak etxera eraman zuen bere silueta.

Bi urteko haurrekin oraindik ez da gorputza lantzen beraiena balitz bezala, oraindik ez dutelako kontzientzia hori, hortaz, beste edozein objekturekin bezala atalen identifikazio-ariketa bat egiten da. Hiru urte dituztenean, ordea, norberarena islatzeko gauza dira, autoezagutzaren bidean egiten da lan. Hori bai, hori horrela egiten da behin haurrek beldurra kentzen diotela siluetak marrazteari, hasieran, ezezaguna den horri beldurra erakusten baitzaio. Beldur horren aurrean behaketaren bitartez parte hartzea errazago suertatzen da: 
Irak4_15/06/15: Gehienak egin gendun, baina batzuk ez zabien nahi, ba bueno nik errespetatu nauen eta... -Irak3_15/06/15: Bai beldurra... -Irak4_15/06/15: Bai, batzuk... -Elk2_15/06/15: Bildurra... -Irak3_15/06/15: Bai, txantxea, lehengo aldian ez zekiten, bat ikusi zutenean ba ya danak nahi zuten egitea silueta hori, baina.

Dena dela, siluetaz gain badaude beste modu batzuk gai hau lantzeko:

Irak3_15/05/27: Orain dela hiru urte bai genituen proiektuak gorputza lantzeko, kantuen bidez, siluetak lurrean edo makinistaren simulazioa eta trena gidari, horrelako gauzak egiten ziren.

Egiteko modu hauek kasu batzuetan bertan behera uzten hasiak direla aipatzen da, nahiz eta oraindik ere beldurra dioten klaseratze modu berriekin esperimentatzeari edota prestakuntza falta sumatu.

Elk2_15/03/03: Baina zuk ezagutzen duzu ikastetxerik hasi dena probatzen esperimentatzen gorputza edo generoarekin beste modu batzuetan klaseratzeko? Irak1_15/03/03:Ez. Elk2_15/03/03: Ez materialik, ez pertsona konkreturik, irakaslerik? Irak1_15/03/03: Egongo da igual, e? Nik ez dut ezagutzen.

Irak1_15/05/18: Sexualitatearen aldetik ere egongo ziren gauza asko ere lantzeko zentzu horretan eta nik uste dut orokorrean irakasleok horren inguruan formazio gutxi dugula.

Bitxia da nola ez duten aipatzen baliabide zehatzik. Jakin badakigu proiektuen bitartez gorputza landu daitekeela, abestiak, ipuinak eta bestelako baliabideak eskuragarri daudela, baina ez dirudi horien analisi sakona egin denik, behintzat aniztasunaren ikuspegitik landu ahal izateko moduan. Hori bai, gorputzaren lanketa egiteko aukera ugari direla aitortzen dute hezitzaileek, bai espazioak, bai momentuak. Batzuek, psikomotrizitate saioak erabiltzen dituzte.

Irak1_15/05/18: Gorputzaren lanketa guk lotu dugu psikomotrizitatean egiten den lanarekin. Nik aurten ez dut psikomotrizitatea ematen baina eskola honetan printzipioz garrantzia ematen zaio eta ditugu zehaztuta sesioak nolakoak izan behar diren.

Azken finean, garapen profesionalak eraman gaitzake jarduera motak eta lanketa egiten den modua errebisatzera, zalantzan jartzera. Eta kasu batzuetan iritzia eta egiteko modua aldatu egiten da. Psikomotrizitate saioak ez dira gorputzaren mugimendu hutsera mugatzen, harago doaz: haurra bere buruarekin zein besteekin harremanetan jartzeko espazioa eta momen- 
tua da. Hortaz, gorputz erlazionalaren ikuspegitik lan egiten da hemen, aukera aniztasuna kontuan hartzeko ikuspegi askoz interesgarriagoa, alegia.

\subsection{ZEHARKAKO LANKETA}

Irakasle gehienek, guztiak ez badira ere, aitortu dute gorputza zeharka lantzen dela, egunerokotasunean, modu naturalean.

Irak6_15/04/16: Bai eta nik uste dut gorputzaren gaia landu egiten dugula, baina guk lantzen dugu edozein momentutan edo egoeratan suertatzen denean gaia.

Beste batzuentzat, edozein elkarrizketatan edota asanbladatan topatu daiteke aitzakia gorputzari buruz hitz egiteko.

Irak2_15/06/15: Bai, da joatea sartzen... «cuando tienes frio como estas?» Ta azkenean umiak, bi urtekuak esaten dotzue «ba hotza dekotenian nau triste ez nau pozik». Ze zu pozik ez zauz hotza zauzenian. $O$ bero zauzenean, nau izarditan ta batzuk dauz pozik ete beste batzuk ez.

Elk4_15/05/27: Nola lantzen duzue gorputza? Irak3_15/05/27: Hemen ez dugu ezer lantzen. Ez dugu lehen bezala, unitate berezi bat izango balitz bezala lantzen, hau da, orain gorputza landuko dugu eta unitate didaktiko honekin landuko dugu, gero nortasuna, gero ingurua... Ez dugu lantzen horrela, gorputzaren momentua iritsi da eta fitxak atera, irudiak jarri, hau neska hau mutila.

Komuna espazio bezala eta pixoihala aldatzeko momentua badira baliabide didaktiko paregabeak gorputzari erreparatzeko, horri buruz hitz egiteko.

Irak3_15/05/27: Gorputza ez dugu lantzen irudi batekin, hemen dago gorputza eta! Painala aldatzean hortxe aprobetxatzen dugu. Painalak ematen digu irakasleoi hitz egiteko aukera gertatzen zaienari buruz, zer sentitzen ari zara, aprobetxatzen dugu gorputz hori maitasunez, errespetuz lantzeko eta hor hitza jartzen dugu. Eta painalak ez dutenak komunera joaten dira eta gainera batzuk ez gaituzte behar baina zorionez gu gertu gaude badaezpada.

Horrelako espazioetan eta momentuetan hezitzailearen papera ondo jokatzea da funtsezkoena.

Irak1_15/06/15: Gero, baita psiko gelan zure gelakoekin batez ere ari dira deskubritzen eta ikusten duzu edozein momentutan ba kuleroak 
jaitsita, igual begiratzen, baina hurbiltzen zarenean geratzen dira horrela, da pixka bat urrunetik ikusten dituzun gauzak oraindikan, zu egon behar zara distantzia batera, beraiek pixkat. Irak4_15/06/15: Hurbiltzen bazara, saiatuten bazara, zelan eta? Ya listo.

Hala ere, zeharkako lanketak ez du zertan emaitza onenak ekarri; aldez aurretiko zalantzan jartze bat ez badago eta hausnarketa prozesu batek gidatutako lana ez bada, indarrean dagoen eredua erreproduzitu egiten da.

Irak6_15/04/16: Nik uste dut konturatu gabe edo askotan konturatzen guk... baina hori gauza askotan gertatzen zaigu, esan det hau eta igual esan behar nuen beste modu batean.

Laburbilduz, hauek izan daitezke gakoak gorputza zeharka modu alternatiboan lantzeko:

- Psikomotrizitate gelan haurrak bakarrik gorputza deskubritzen uztea, irakasleak urrunetik ikusi behatzen duen bitartean; eskuhartze minimoa egitea.

- Pardela aldatzean aprobetxatzea sentimenduei buruz hitz egiteko eta gorputza maitasunez eta errespetuz tratatzeko.

- Haurrak komunera doazenean irakasleek gertu egon behar dute, haurrek sostengurik behar badute.

\subsection{MARKOA, KOKAPENA}

Gorputza, beste edozein gai bezala, lantzeko orduan ikastetxeek hausnarketa egin behar dute non kokatzen diren erabakitzeko, nola landu, zein helbururekin, zein baliabide eta espazio erabiliko dituzten, etab. Betiere curriculumaren zehaztapenak kontuan hartzen direla, edo ez...

Ikastegi batzuk berriak diren neurrian ez dute momentuz hausnarketa sakona egin gorputzaren lanketaren inguruan, ez dute ildorik zehaztu.

Irak8_15/04/16: Eskola oso berria da, orduan horrek esan nahi du ez dugula nahiko genukeen, gauzak egin behar dira zerotik, ordun, batzuetan ez dugu, aurten behintzat momentua izan ikasturtean zehar, ba, ikusteko igual ba nola landu horrelako gai potoloa, niretzat gorputza oso gai garrantzitsua da, baina igual hori, gaude bakoitza pues bere mailarekin adosten duen bezala jokatzen eta eskola bezala ba orain arte ez dugu tarterik izan..... Igual ildoa zehazteko...

Hala ere, ikasmailaka badirudi erabakiren bat hartuta dutela, izan ere landu beharreko gaia den neurrian behin-behineko plangintza bat egiteko beharra sentitzen dute. 
Irak2_15/04/16: Guk, orduan eskola berria denez eta antolatzen ari garenez, hori atzo berez egon ginen antolatzen, ez errepikatzeko, klaro bakoitza hasi zen korrika batean hasi behar gara gaiekin eta ez genuen elkartu eta esan zuek egiten duzue hau eta guk hau ez errepikatzeko eta hori guztia. Gutxi gorabehera gorputzaren gaiarekin zehaztu genuen 2 urteko gelan egiten duguna, adibidez gure unitatea deitzen da «Ni neu», kontua da bi urteko umeak direla, oraindik gauza asko landu egin behar dira eta ez dute kontzientzia hori, batzuk ez dakite oraindik zein den neska eta zein mutila, hori lantzen dugu eta aipatzen dugu, baina berez lan egin duguna da bakoitzaren, hasi gara aurpegiarekin eta gauza errazak eta pixkat... Irak5_15/04/16: oinarrizko atalak... Irak2_15/04/16: oinarrizko gauzak, gero adibidez esan genuen eskema korporala gero landuko zela gehiago 3 urteko gelan, oraindik ez ziren kapaz 2 koak.

Bi urteko gelan bi estrategia aipatzen dira, bai zeharkako lanketa, bai komuna espazio natural gisa erabiltzearena. Baina ez da zehaztapen handiarekin lantzen gorputza, nahiko modu orokorrean egiten da. Hitz horietan argi erakusten da oraindik ere sexu organoak lotzen direla sexu-identitatearekin, hau da, ikuspegi binarista gailentzen da. Lanketa erraza dela aipatzen dute, nahiz eta mugak onartu, oso ondorio sinpleak ateratzen dituztelako, baina ez norberaren ezagutza horrelako prozesu konplexua delako: aldakorra da, dinamikoa, beraz, sexu-genero sistema barneratu dutenek hura deseraiki eta norberarena sortu behar dute, haurrek hasieratik aukera guztiak dituztela eurena eraiki dezaten.

Irak5_15/04/16: Baina nik uste 2 urteko gela dala oso txikiak baina oso aproposa, ze hasten direnez esfinterren kontrolarekin, eurak naturalki hartzen dute generoaren edo sexuaren desberdinketa hori, orduan ikustea ba hori, bai neska eta mutila, zerk desberdintzen gaitu fisikoki niretzako hori oso era naturala da eurak ikasteko. Irak4 Gertatzen dana da gelditzen direla bakarrik neskak alua mutilak zakila. Irak5_15/04/16: Bai.

Oinarrizko gorputz atalak landu daitezke unitate didaktikoen bitartez eta normalean aurpegiarekin hasten dira. Hala ere, ez litzateke derrigorrezkoa atalen lanketa egitea hiru urteko gelan sartu arte; alde batetik, curriculumak horrela zehazten duelako eta, bestetik, gorputz-eskema garatu arte zentzurik ez duelako. Baina ikastetxe guztiek ez dute modu berean ulertzen adin bakoitzean landu beharrekoa; batzuk goiz eta modu espezifikoan hasten diren bitartean, beste batzuek lau-bost urte arte itxoiten dute, edota ez dute inoiz modu zuzenean lantzen.

Irak4_15/06/15: Gero gu hiru urteko gelan hasi ginen desberdintasunak apur bet edo konparaketak egiten, bueno handiagoa, txikiagoa, ho- 
rrela kontzeptu batzuk landuteko bebai. Irak1_15/06/15: Uste dut 2-3 urteko gelan dela orokorrago eta gero 4-5urtekin hasten garela ia gehiago zehatzago, pues si bekainak, begiak... Irak3_15/06/15: hezurrak, giharrak...

Irak1_15/05/13: El tema del cuerpo, no lo tenemos como un tema específico, no lo tenemos como una unidad didáctica. Lo que sí es que lo vemos de manera transversal. El cuerpo lo tratamos de una forma muy sencillita, no nos metemos en profundidad, o sea lo que son las partes del cuerpo, el cuerpo de lo que es un niño, de lo que es una niña, y no vamos mucho más allá, diferenciarlas bien, hombre, luego ya nos metemos en el cuerpo de su mamá, en cómo nacen los niños, también como influyó su papa ahí, pero de una forma contada a nivel muy didáctico. Tratamos también como se reproducen las especies, los animales, lo vemos en directo. Hombre lo del cuerpo de una mama todavía no, la verdad es que nos parece un poco fuerte. Pero si que intentamos darle mucha naturalidad a eso.

Zentzu horretan, esan daiteke guztiak nahiko ados daudela, gorputzaren gaiarekin landu daitezkeelako ez bakarrik gorputz-atalak, baizik eta tamainak, azal-koloreak eta arrazak, genero identitatea eta beste hainbat arlo. Azken finean, gorputza lantzearen helburua autoezagupena da zentzu zabalean ulertuta.

Elk1_15/3/15: Eta, zuen ustez, hemen, hau guztia kontuan izanda, zein izango litzateke gorputza lantzearen helburua? Irak1_15/3/15: Autoezagupena, norberaren ezagutza, eta batez ere gustura egotea beren gorputzarekin, hau da, lortzen dituzten ahalmen guztiak garatzea, disfrutatzeko, gozatzeko gorputzarekin, ez izateko lotsarik, beldurrrik ez izateko, batez ere, momentu honetan, da hori ikustea gorputza disfrutatzeko herraminta bezala eta aukera guztiak. Elk1_15/3/15: Bai gorputzaren aukera guztiak. Irak1_15/3/15: Bai batzutan ez dute, kostatzen zaie, testura ezberdinekin harremantzea, ba ez, ba, saiatuko gara esperientzia desberdinen bitartez...

Laburbilduz, denek gorputza gai garrantzitsutzat hartzen dute, baina haurren adin tartearen arabera gaia ikuspegi desberdinetatik lantzen dute, normala den bezala. Oraindik ere ikuspegi binarista da nagusi, baina gorputza-erlazionalaren ideia nahiko barneratuta dutela sumatzen da. Esperimentaziotik abiatu nahi dute, gorputzaren harreman natural eta osasuntsua bultzatu nahian, baina oraindik ere hausnarketa eta formakuntza falta identifikatzen dira. 


\section{Ereduak, irudikapenak}

Gorputza, hasieratik ikusi dugun bezala, gaur egungo gizartean oraindik bada tabua, aipatzen ez den gaia, ekiditen dena. Horretaz kontziente, leku batzuetan tabuak kentzeko hainbat estrategia erabiltzen ari dira, beste batzuen artean, errealak diren gorputz biluzien irudiak (ereduak) erabiliz eta zuzenean eta eskuragarri dauden gorputz horien behaketaren bitartez:

Irak1_15/3/15: Besterik ez dugu egiten; gero, bai saiatzen garela tabu guztiak kentzen, gorputz biluziak arte ederretan eta orain bakarrik daude erretratuetan baina beno bilatu ditugu, margolariak ezagutu, margoak eta horiek ipintzen eta gero ipiniko ditugu benetako argazkiak, familiak, familia oso bat biluzik eta hori haiek ikusteko.... Gero, batzuk ez dakit benetan, ez dakite islatzen, adibidez, mutilek ez dakite oso ondo nolakoa den zakila, barrabilak, beno, bagoaz komunera ispiluarekin, eta begiratu ondo eta aztertu. Elk1_15/3/15: Hori egiten duzue? Irak1_15/3/15: Bai. Elk1_15/3/15: Hau da, komunera joan eta aztertu. Irak1_15/3/15: Bai, eramaten dugu ispilu hori (ispilua seinalatu du). Eta, beno, ez dakizu, batzuk bai badakite, baina beno, beste batzuk ez, orduan, bai, bagoaz. Eta hemen ere, ba, berehala hasiko dira lotsarekin baina hemen egin dugu, margotzen ari dira ba kanpoan neska bat biluzik eta hemengo neska bati berdin zitzaion igotzea eta ikusi dugu guztia.

Irak3_15/05/19: kontua da, neska naiz edo mutila naiz, eta ez banaiz. neska edo mutila? Hori be bai landu genuen ikastaroan, orduan ba gorputza eta ez ditugu desberdinketak egiten. Komunera joaten garenean, arreta deitzen die biluzten direnean, biluzik daudenean begiratzen ditugu parekotasunak...

Horrelako estrategiei esker gorputzaren irudikapen mentala egingo dute umeek, eta marrazkietan islatuko. Giza-irudiaren margoetan eskola batean ondorioztatu dute neskek detaileak gehiago zaintzen dituztela:

Elk2_15/06/15: Eta ikusi dozue diferentziarik nola marraztu dituzte zuen kasuan edo nola dekoratu zituzten zure kasuan neska eta mutilen artean? Eurek egiten dutena esan nahi dut dekoratzeko edo? Irak4_15/06/15: Bai, nik nire gelan oso argi ikusten dot mutil batzuk ondiño ez dabizenak giza irudia margoztuten eta neskak orokorrean deukie afizio gehiau edo ez dakit, ez danak eh, baina batzuk bai. Eta neskak mas detallistas eta bat erakutsi notzuen marrazkie, ume baten kasuan justo, ilea, egin zauen bueno, beraien artean dekei pues harremana ta berak irudikatu zauzen lau pertsona eta etorri izan nigana eta Nora begitu. Ta ni a ze polita eta nortzuk dira? Ta derrepente esaten dozta: Los aitas, todos los aitas de la kuadrilla. Lagunen gurasoak eta bakoitzari ba hori, ba batek deko ilea pixkat pintxo ta horrela, besteari kizkurra, besteak. 
Bai oso, ta tamaina desberdinek ta kuriosoa. Irak3_15/06/15: Kurioso. Irak4_15/06/15: Marrazkia kurioso bai. Elk2_15/06/15: Ta hori neskato batek? Irak4_15/06/15: Bai, neska da bai.

Argi dagoena da marrazkiek erakusten dutela adinarekin batera gertatzen den garapena, izan ere kognitiboki zein arlo psikomotorean aurrerapauso nabariak ematen dira Haur Hezkuntzan. Hasieran, burua da garrantzitsua (2 urte), gorputzaren antzekoak diren zirriborroak gero (3 urte), ondo irudikatu arte (4-5 urte), azal-koloreekin, ile motak, arrazak...

Irak1_15/06/15: Nik 4 urteko gelan landu nuenean, kuriosoa da ze egiten dute burua eta gero besoak ateratzen dituzte belarrietatik. Jo polita da ze hori igual 4 urteko edo 5 urteko gelan zure gorputza irudikatzeko, marrazteko esaten diezu trimestrean behin eta ikusten da eboluzioa. Adibidez, 1. trimestrean egiten dute gainetik eta gero ya poliki-poliki juten direla. Elk2_15/06/15: Bueno inportantea da burua, gero ya apurka-apurka etorriko da gorputza. Irak1: Nik uste dot 5 urte ta. Irak4_15/06/15: Nik uste hasieran da gehien bat, gehienak da burue eta eurek uste dabe, igual pues batzuk begiek, baina bestela da borobil bat eta zapaburuak. Irak3_15/06/15: Nire gelan, bat hasi da, bakarra, neska bat, hori ba borobil bat eta hortik dena irteten begiak, eskuak, hankak. Irak4_15/06/15: eta gero ya, hasten dire zehaztuten gehiau, baina nik uste dot 4 eta 5 urteko gela dala... Irak1_15/06/15: Aukera gehiago ematen du. Irak4_15/06/15: Hiru urteko gelan nik uste dot dala saltoa garabatotik hasten dirala ya monigoteak edo holako... Irak3_15/06/15: Ya garatuau... Irak4_15/06/15: Hori, igual ez dakit, dana bat, osea irudi bat izatetik pues ya hasten dire.

Edozein kasutan, irudikapenak ez dira osatzen bakarrik eskolan lantzen den horrekin. Horregatik, irakasleek oso argi dute familietan ikusi eta bizi dutena baldintzatuko duela guztiz garapen eta ikaskuntza prozesua.

Irak1_15/06/15: Beraiek oraindikan ez dira. Orain hasi direla ya txiza egiten, pues normalean ohitura dugu txiza egiteko eserita denek, bat edo beste como mi aita, hasten da zutik, aurrekoan neska bat hasi zen bebai zutik. Ta esan giñun eske zuk ezin dozu zulora bota, izan zen gauza bat kar kar. Baina bestela beraiek ez dira. (...) Irak4_15/06/15: Eta pues tiene la pocheta eta ez dakit, eta holan, eta gero bai hasten die 3 urteko gelan, neskak gehienbat, nire gelan ikusi dudan kasuagatik, bueno lau bi dekotela, osea igual neskak fijatzen dira beti amaren, beti titietan eta igual dekozu titi handiak ama bezela, nik zergatik ez? edo igual Oihane yo no tengo tetas como ama no sé que y tu si o bueno ya hasten zara, nik azaldu nien apur bet holan holan hasi ginen, atarako dodaz irudiek eta ikusiko dogu eta ba hori biluzik eta neska eta mutile, 
eta baina bueno orain jartzen badut gainean hau, orain ez da ikusten ez zakila ez alua. Orduan nola dakigu neska edo mutila den? Eta orduen eurak hasi ziren tiene el pelo largo, tiene el pelo corto tal y luego ya. Baina gero hasi ginen eta ez dakit batek esan zauen, si pero es que mi ama tiene el pelo corto también. Digo karo. Irak1_15/06/15: Y mi aita el pelo largo. Irak4_15/06/15: y mi aita el pelo largo, eske karo ya hor, ya hasten gara, orokorrean, pues bai ikusten da mutilen kasuan ule laburra, baina danak ez dekie zetan. Ya hasten zara elkarrizketa hor sortu zan. Bueno nik egun baten landu nauen holan, baina ez dakit natural-natural.

Hor egongo litzateke gakoa, umeen bizitzan dagoenari erreparatuz intereseko gaiak aukeratu eta tabuak apurtzen joateko. Erreferente gehienak telebista eta etxetik heltzen zaizkie, eta hortik hasten dira eraikitzen binarismoa 3 urtetik aurrera. Irakasleek uste dute telebistatik, eta bertatik eratorritako marketinetik, jasotzen dituztela muturreko erreferente binarista asko. Etxean ikasten du hasieran eta gero eskolarako saltoa ematen $\mathrm{du}$, bertan irakasleek lan egiten dutelarik erreferente «egokiak» transmititu eta zabaltzeko. Nolako aukerak ematen dituzte? Sozialki onartutakoetatik haragoko proposamenak oraindik gutxi direlakoan gaude, ez dutelako «bestelako ereduak» erakusteko beharrik sentitzen edo nola egin ez dakitelako.

\section{Ondorioak}

Lan honen helburu nagusia Haur Hezkuntzan generoari lotuta gorputzak duen presentzia eta hezitzaileek nola lantzen duten aztertzea izan da. Horretarako, hainbat elkarrizketa eta eztabaida-taldeak egin dira hezitzaileen ikuspegia ezagutzeko asmoz. Haur Hezkuntzako irakasleek genero identitatearen inguruko kezka adierazten dute, prestakuntza falta salatzen dute eta hausnarketarako espazioa eta denbora faltan botatzen dituzte. Baliabide eta prestakuntza falta nagusi dira maiz; izan ere horren beharra sentitzen eta adierazten da, zenbait ikerketatan ikus daitekeen bezala (Gorrotxategi eta Alvarez, 2017; Romero eta Abril, 2012).

Gorputza ez da guztiz lotzen identitatearekin, nahiz eta gure identitatea hertsiki lotuta dagoen gorputz batean bizitzeko esperientziari (Bloom, 2006). Batzuetan zer den esateko ere zailtasunak dituzte, gizartean tabu bat den seinale. Baina lan honen mugetako bat hau izan daiteke: zuzenean galdera egin ez denez (Zer da gorputza?), hezitzaileek ez diote kontu horri erreparatu. Hortaz, benetan ez dakigu gaiari buruzko hausnarketa egiten den edo irakasle bakoitzak barneratutakoarekin lan egiten duen.

Gorputzari eta sexu-identitateari lotutako irudikapenen garrantziaz ohartzen dira, izan ere helduok estereotipoak eta rol tradizionalak barneratuta ditugula diote eta, hausnarketa eta kritika ariketa egin ezean, horiek 
erreproduzitzeko arriskua argia dela onartzen dute. Heteronormatibitatearekin apurtzeko beharra ez da berria eta horretarako prestakuntza eta hausnarketa lehendabiziko pausoak dira; hala ere, maiz ez dira baldintza horiek betetzen, estereotipoen erreprodukzioari eusten baitzaio(Quaresma da Silva eta Ulloa, 2011; Silva eta Megid, 2006). Begirada desberdin batek hezitzaileak bere buruari so egiteko proposatuko du barneratutako diskriminazio, aurreiritzi eta biolentziak aurkitu eta aztertzeko. Horrekin batera, genero identitateak harremanei eta sozializazioari begiratuko die eta heteronormatibitatearen markoa agerian utziko du: pertsona guztiak heterosexualak ez garenez ezin dela umerik orientazio sexual zehatzera bultzatu, eta generoa egin, desegin eta berregin daitekeela erakutsiz (Blaise, 2012).

Zalantza da beharrezko baliabide nahikorik gabe ea begirada berria gara daitekeen: nola gainditu estereotipoak eta binarismoa, eta ondorioz, gorputz-eredu anitzak nola eskaini? Hezitzaileek mahai gainean jartzen zuten beste arazoetako bat plangintza faltarena da; nahiz eta jakin gaiak berebiziko garrantzia duela, nahiz eta araudiak (curriculumak) langai eta helburu konkretuak zehazten dituen, euren lanaren plangintzan ez da ezartzen helburu espezifikorik. Zailtasun hori areagotzen da, gainera, berriak diren ikastetxeetan: ikastetxearen proiektua itxi gabe dute eta irakasle talde egonkorrik apenas dagoen, ikasturtekako plangintza egiten duten arren. Hau da, haurren adina eta garapen ezaugarriak kontuan hartzen dituzte eta ikasmailaka antolatzen dute lana, baina ez dute adierazten zein edo zeintzuk diren helburuak jarduerak egiteko orduan. Sentsazioa da badakitela eduki hori landu behar dutela, baina ez dagoela sakoneko hausnarketarik.

Tradizioak dio gai hau planifikatu egin behar dela, jarduerak diseinatzen direla gaia modu esplizituan lantzeko, alegia. Jarduera arruntenen aurrean (siluetak, hiztegia lantzea, proiektuak) esperimentatzeari beldurra diotela onartzen dute, prestakuntza falta sentitzen dutelako. Hori arazo bat da sexu eta generoaren irakaspena aldatu nahi bada gure gizartean; gogoa badago baina gaitasun eta segurtasun falta ere bai (Mayor, 2015).

Bestalde, ez dituzte material gehiegi aipatzen; lan honen helburuetako bat izan da gaia lantzen duten baliabideen analisia egitea eta horren analisi deskriptiboa eranskinetan eskaintzen da, hezitzaileen interesekoa izan daitekeelakoan. Hala ere, horren analisi kritikoa egiteko dago eta, zuzenena, irakasle talde bakoitzak bere hausnarketa egin ostean eta proiektua definituta edukita, materialak errebisatzea izango litzateke. Horrela, partekatzen diren helburuak lortzeko bidea egiteko lehen pausoak emango lituzkete, benetan lortu nahi den eskolarako bidea, alegia.

Aldi berean, gorputza etengabe eta modu inkontzientean lantzen den gaia da, baliabide konkreturik gabe, asanbladan, elkarrizketa arruntetan, psikomotrizitatean, komunean, etab. Hain zuzen ere, barneratutako eredu, estereotipo, irudikapen eta jarrerak agertzen direnean, hortaz, nola egin lanketa eraginkorra nahi ditugun helburuen arabera? Hau da, nola lortu ikuspegi binarista gainditzea eta hortik kanpo geratzen direnen bazterkeria 
gainditzea (Gorrotxategi eta Alvarez, 2017) eta gorputz eta genero aniztasunetik lan egitea? Hemen ondorioztatzen ditugunak dira, gutxienez, hurrengo hiru estrategiak: prestakuntzarako aukera gehiago, hezitzaileen artean hausnarketarako espazioak eta kalitatezko materialen errebisioa eta hautaketa.

Hezkuntzaren helburua, eta bereziki Haur Hezkuntzarena, ikasleak jendarterako prestatu eta bizitzen ikas dezaten bada, irakasleak etengabe prestatzen ibili behar dira: gorputzaren eta genero identitatearen gaiari begira, esan bezala, haurrak izango diren pertsona eraikitzen has daitezen eskura ahalik eta aukera gehien dituztela erakutsiz.

\begin{abstract}
The present work intends to approach the conception that professionals of the Infant Education have about on the body, in relation to gender identity. Given the increasingly widespread discourse on the need to overcome a binarist model (male or female), in the 5 interviews and in the 5 discussion groups analyzed here, various difficulties are identified, among others, absence of training and time for joint reflection, lack of stability of the templates in schools and, finally, defined projects. Educational activities in preschool classes are carried out following two main approaches: on the one hand, there is a direct, explicit work, through traditional methodological resources such as silhouettes or something more innovative such as small projects; and, on the other hand, a transversal work that is carried out on a day to day basis in the usual spaces as «txokos», assemblies or toilets. However, there is doubt about the real change, since the scope of activities with explicit objectives is more limited, whereas the work that is most effective, the transversal one in its words, is seldom preceded by the necessary conditions: training, reflection and joint definition. A review of the didactic resources available in Basque is also carried out.
\end{abstract}

Keywords: Infant Education, body, methodology, gender identity, coeducation.

El presente trabajo pretende acercarnos a la concepción que profesionales de la Educación Infantil tienen sobre el cuerpo, en relación a la identidad de género. Ante el discurso cada vez más extendido sobre la necesidad de superar un modelo binarista (hombre o mujer), 
en las 5 entrevistas y los 5 grupos de discusión que aquí se analizan se identifican diversas dificultades, entre otras, la ausencia de formación y de tiempo para la reflexión conjunta, la falta de estabilidad de las plantillas en los centros escolares y la escasez de proyectos definidos. El tipo de actividades en las aulas de la etapa infantil se combinan: por un lado, hay un trabajo directo, explícito, a través de recursos metodológicos tradicionales como las siluetas o algo más innovadores como pequeños proyectos; $y$, por otro lado, un trabajo transversal que se realiza en el día a día en los espacios habituales como los txokos, las asambleas o los aseos. Sin embargo, se duda acerca del cambio real, puesto que el alcance de las actividades con objetivos explícitos es más limitado, mientras que el trabajo que es más efectivo, el transversal en sus palabras, pocas veces está precedido de las condiciones necesarias: formación, reflexión y definición conjunta. Se realiza, también, una revisión de los recursos didácticos disponibles en euskera.

Palabras clave: Educación Infantil, cuerpo, metodología, identidad de género, coeducación

Le présent travail tente d'approcher la conception que les professionnels de l'Education des Enfants ont sur le corps, en relation avec l'identité sexuelle. Compte tenu du discours de plus en plus étendu sur le besoin de surpasser un modèle binariste (masculin ou féminin), sur les 5 entretiens et les 5 groupes de discussion analysés ici, on identifie un certain nombre de difficultés, notamment le manque de formation et de temps pour une réflexion commune, manque de stabilité du personnel dans les écoles et manque de projets définis. Les formes de travail dans les classes maternelles combinent: d'une part, il y a un travail direct et explicite, à travers de ressources méthodologiques traditionnelles telles que les silhouettes, ou d'autres plus innovants, telles que les petits projets; et, d'autre part, un travail transversal qui se réalise au jour le jour dans les espaces habituels, que ce soit dans les «txokos», dans les assemblées ou dans les toilettes. Cependant, il se pose le doute sur le changement réel, puisque la portée des activités avec des objectifs explicites est plus limitée, tandis que le travail le plus efficace, le transversal dans ses mots, est rarement précédé des conditions nécessaires: formation, réflexion et définition conjointe. Une revue des ressources didactiques disponibles en euskera est également réalisée.

Mots-clé: Éducation Préprimaire, corps, méthodologie, identité des genres, coéducation. 


\section{ERREFERENTZIAK}

Anzieu, D. (2003). El yo-piel. Madrid: Biblioteca Nueva.

Batzuen artean (2009a). Urtxintxa 3 urte. Irakaslearen liburua. Donostia: Elkarlanean. ISBN: 978-84-9783-669-2.

Batzuen artean (2009b). Urtxintxa 5 urte. Irakaslearen liburua. Donostia: Elkarlanean. ISBN: 978-84-9783-147-6.

Batzuen artean (2010). Urtxintxa 4 urte. Irakaslearen liburua. Donostia: Elkarlanean. ISBN: 978-84-9783-668-9.

Benítez, J. L., eta Fernández, M. (2010). Desarrollo afectivo, emocional y de la personalidad. A. Muñoz-en, Psicología del desarrollo en la educación infantil (121-140. or.).

Bick, E. (1991). A experiência da pele em relações de objecto arcaicas. In E. B. Spillius (Ed.), Melanie Klein Hoje, 1 (194-198. or.). Rio de Janeiro: Imago.

Blaise, M. (2013). Genero erregulazioak. Castillo, I. eta Retolaza, I.(Ed.), Genero ariketak. Feminismoaren subjektuak (249-276. or.). Donostia: EDO!

Bloom, K. (2006). The embodied self. London: Karnac Books.

Botella, L., Grañó, N., Gámiz, M., y Abey, M. (2008). La presencia ignorada del cuerpo: Corporalidad y (re)construcción de la identidad. Revista Argentina de Clínica Psicológica, 7, 245-263.

Cash, T. F., eta Pruzinsky, T. (1990). Body images: development, deviance and changes. Nueva york: Guilford Press.

Dolto, F. (1984). La imagen inconsciente del cuerpo. Barcelona: Paidós.

Eusko Jaurlaritza (2016ko urtarrilaren 15a). Oinarrizko Hezkuntzako Curriculuma. 236/2015 Dekretua. https://www.euskadi.eus/y22-bopv/es/bopv2/ datos/2016/01/1600141a.pdf-tik berreskuratuta, 2017ko martxoaren 15an.

Eusko Jaurlaritza (2016ko urtarrilaren 15a). Haur Hezkuntzako Curriculuma. 237/2015 Dekretua. https://www.euskadi.eus/y22-bopv/es/bopv2/ datos/2016/01/1600142a.pdf-tik berreskuratuta, 2017ko martxoaren 15an.

Gorrotxategi, M., eta Alvarez, A. (2017). Genero desadostasuna Haur Hezkuntzan. Irakasleon erronka berria. Tantak, 29(1), 95-122. DOI: 10.1387/tantak.17867

Hoffman, L., Paris, S., eta Hall, E. (1995). Desarrollo social: Conventirse en una persona. En L. Hoffman, S. Paris eta E. Hall-en, Psicología del desarrollo hoy (pp. 180-208.

Ibaizabal (2013a). Nubaris dimentsioa. 2 urte. Amorebieta: Ibaizabal. ISBN: 9788483947241.

Ibaizabal (2013b). Nubaris dimentsioa. 3 urte. Amorebieta: Ibaizabal. ISBN: 9788483947272.

Ibaizabal (2013c). Nubaris dimentsioa. 4 urte. Amorebieta: Ibaizabal. ISBN: 9788483947333.

Juaristi, P. Gizarte eta ikerketarako teknikak. Teoria eta adibideak. Leioa: UPV/ EHU.

Lecompte, M. D. (1995). Un matrimonio conveniente: Diseño de investigación cualitativa y estándares para la evaluación de programas. RELIEVE 1(1). https://ojs.uv.es/index.php/RELIEVE/article/view/6322/6072 -tik berreskuratuta, 2011ko maiatzan. 
Mayor, A. (2015). Niñas con pene y niños con vulva: comprender para poder apoyar. https://www.youtube.com/watch? $\mathrm{v}=\mathrm{x} 0 \mathrm{VDdR}$ H HcuM 2016ko azaroaren 3 an kontsultatua. Hitzaldia Gorlizeko ikastetxe publikoan.

Merleau-Ponty, M. (1999). Fenomenologia da percepção. São Paulo: Martins Fontes.

Mora J. eta Palacios, J. (1999). Garapen fisikoa eta psikomotorea eskolaurreko urteetan zehar. J. Palacios, A. Marchesi eta C. Coll-en, Garapen psikologikoa eta hezuntza. Psikologia ebolutiboa (pp. 143-154).

Palacios, J., eta Hidalgo, V. (1999). Nortasunaren garapena eskolaurreko urteetan. J. Palacios, A. Marchesi eta C. Coll-en, Garapen psikologikoa eta hezuntza. Psikologia ebolutiboa (pp. 225-238).

Pankow, G. (1981). L'être-là du schizofrène - contribuition à la méthode de structuration dynamique dans les psychoses. Paris: Aubier-Montaigne.

Parisoli, M. M. (2002). Penser le corps. Paris: Puf.

Quaresma da Silva, D., eta Ulloa, O. (2011). Prácticas de educación sexual: Un análisis en escuelas municipales del sur de Brasil. Archivos Analíticos de Políticas Educativas, 12(69). http://epaa.asu.edu/ojs/article/view/224tik berreskuratuta, 2011ko maiatzan.

Quaresma da Silva, D., Sarmento, D. F., eta Fossatti, P. (2012). Género y sexualidad: ¿Qué dicen las profesoras de Educación Infantil de Canoas, Brasil? Archivos Analíticos de Políticas Educativas, 20(16), 1-20.

Ribeiro, A. (2003). O corpo que somos: Aparência, sensualidade, comunicação. Lisboa: Notícias.

Romero, A., eta Abril, P. (2008). Género y la formación del profesorado en los estudios de Educación Infantil. Revista Electrónica Interuniversitaria de Formación del Profesorado, 11(3), 43-51.

Schilder, P. (1999). A imagem do corpo - as energias construtivas da psique. São Paulo: Martins Fontes.

Silva, R. C., eta Megid, N. J. (2006). Formacao de profesores e educadores para abordagem da educacao sexual na escola: o que mostram as pesquisas. Ciencia \& Educacao (Bauru), 12(2), 185-197.

Stipek, D., Gralinski, H., eta Kopp, C. (1990). Self-concept development in the toddler years. Developmental Psychology, 26, 972-977.

Taylor, S., eta Bogdan, R.C., (1986). Introducción a los métodos cualitativos de investigación. Barcelona: Paidos.

Tisseron, S. (1997). Psychanalyse de l'image: des premiers traits au virtuel. Paris: Dunod.

Von Doellinger, O. (2011). Cuerpo e identidad. Estereotipos de género, estima corporal y sintomatología psiquiátrica en una muestra universitaria. Tesis doctoral. Blanquerna: Universidad Ramon Llull.

Ziarsolo, A., Elorza, C., Martínez, M. C., Otsoa, N., eta Burgoa, A. (1997). Proiektuen bidez irakasteko esperientzia bat. Nor naiz ni? Eusko Jaurlaritzan, Haur Hezkuntza gelarako proposamenak (3-6 urte), (24-46 orr.). Zarautz: Itxaropena. 


\section{ERANSKINA}

\section{Gorputza eta genero identitatea lantzeko materiala}

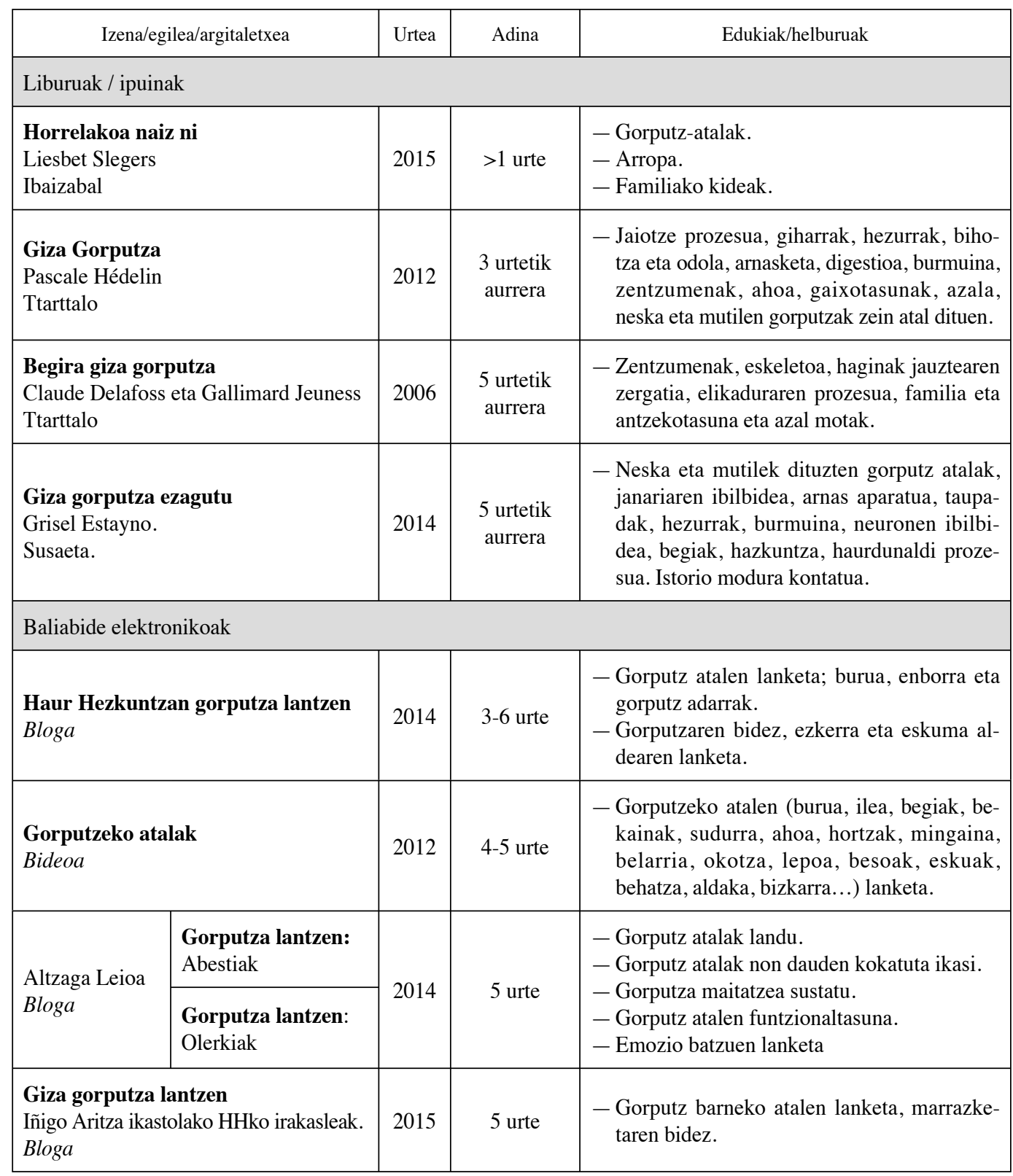




\begin{tabular}{|c|c|c|c|c|}
\hline \multicolumn{2}{|c|}{ Izena/egilea/argitaletxea } & Urtea & Adina & Edukiak/helburuak \\
\hline \multicolumn{2}{|c|}{$\begin{array}{l}\text { Giza gorputza } \\
\text { Garazi Alonso, Garazi Prieto eta } \\
\text { Yasmina Regueiro. Bloga. Proiektua } \\
\text { izaera. }\end{array}$} & 2010 & 5 urte & $\begin{array}{l}\text { - Haurrek euren gorputza barrutik eta kanpo- } \\
\text { tik hobeto ezagutzea du helburua. } \\
\text { - Honetaz gain, bakoitzak gorputzeko oina- } \\
\text { rrizko beharrak identifikatzea, kontrolatzea, } \\
\text { adieraztea eta arautzea, norberaren gaitasune- } \\
\text { tan konfiantza izanez. }\end{array}$ \\
\hline \multicolumn{2}{|c|}{$\begin{array}{l}\text { Gure gorputza barrutik eta kanpotik. } \\
\text { Yurdana, Nahikari eta Nerea (ikasleak). } \\
\text { Bloga }\end{array}$} & 2010 & $\begin{array}{l}5 \text { urtetik } \\
\text { aurrera. } \\
\text { Jardueraren } \\
\text { arabera } \\
\text { aldatu } \\
\text { daiteke }\end{array}$ & $\begin{array}{l}\text { - Nolakoa da giza gorputza. } \\
\text { - Gorputzaren organoak. } \\
\text { - Digestio prozesua. } \\
\text { - Gorputzarekiko begirunea beraien gorputza } \\
\text { ondo ezagutzeko eta maitatzeko. }\end{array}$ \\
\hline \multicolumn{5}{|l|}{ Proiektuak } \\
\hline \multirow{2}{*}{$\begin{array}{l}\text { TU-TUUU } \\
\text { Giltza-Edebe } \\
\text { taldea }\end{array}$} & $\begin{array}{l}\text { 1.unitatea: Tutu trena } \\
\text { eskolan }\end{array}$ & \multirow{2}{*}{1999} & \multirow{2}{*}{2 urte } & $\begin{array}{l}\text { - Gorputz atalak. } \\
\text { - Aurpegiko elementuak. } \\
\text { - Sexu identifikazioa. }\end{array}$ \\
\hline & $\begin{array}{l}\text { 2.unitatea: Tutu } \\
\text { hotzez dago }\end{array}$ & & & $\begin{array}{l}\text { - Gorputzaren zainketa. } \\
\text { - Hotza sentitzea zer den ezagutu. }\end{array}$ \\
\hline \multicolumn{2}{|c|}{$\begin{array}{l}\text { Gorputza. SM eskola ibiltaria } \\
\text { Edebé } \\
\text { - 1. unitatea (Eskolara goaz) + ipuinak } \\
\quad \text { + abestiak + etab. }\end{array}$} & 2010 & 3 urte & $\begin{array}{l}\text { - Norberaren ezagutza eta autonomia pertso- } \\
\text { nala. } \\
\text { - Haurrak egokitu eta ikastetxea, ikaskideak } \\
\text { eta beren gorputza bera ezagutzea izango da } \\
\text { helburua. } \\
\text { - Neska-mutilek beren gorputza gero eta } \\
\text { gehiago ezagutu eta kontrolatuko dute: eu- } \\
\text { ren sexua bereizten ikasiko dute. }\end{array}$ \\
\hline \multicolumn{2}{|c|}{$\begin{array}{l}\text { Haur Hezkuntza gelarako } \\
\text { proposamenak: Nor naiz ni? } \\
\text { Eusko Jarularitza }\end{array}$} & 2003 & $3-6$ urte & $\begin{array}{l}\text { - Album txiki bat egitea. } \\
\text { - Bakoitzaren datu pertsonalak lantzea eta } \\
\text { adieraztea. } \\
\text { - Zeharka nola jaiotzen garen landu. } \\
\text { - Generoa ez da aipatzen. }\end{array}$ \\
\hline \multicolumn{2}{|c|}{$\begin{array}{l}\text { Norberaren ezagutza eta autonomia } \\
\text { pertsonala } \\
\text { Agrega Proiektua. Bloga. } \\
\text { 1.sekuentzia. Gorputza eta adierazpena. } \\
\text { 3.sekuentzia. Gorputzaren eskema } \\
\text { 6.sekuentzia. Giza aurpegia }\end{array}$} & $\begin{array}{l}2010 \\
- \\
2011\end{array}$ & $3-6$ urte & $\begin{array}{l}\text { - Gorputzeko zati nagusiak zein diren identi- } \\
\text { fikatzeko segida didaktikoa da. } \\
\text { - Gorputz zati hauek zertarako balio duten } \\
\text { azaltzen da. }\end{array}$ \\
\hline
\end{tabular}




\begin{tabular}{|c|c|c|c|c|}
\hline & & Urtea & Adina & Edukiak/helburuak \\
\hline \multirow{10}{*}{ 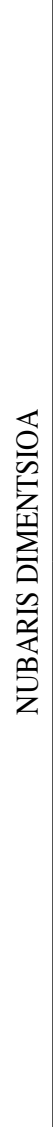 } & $\begin{array}{c}\text { 1.unitatea: } \\
\text { Goazen eskolara }\end{array}$ & \multirow{10}{*}{2013} & \multirow[b]{2}{*}{2 urte } & - Neska mutil kanpoko itxuraren lanketa. \\
\hline & $\begin{array}{l}\text { 2.unitatea: } \\
\text { Ispilutxo, ispilutxo }\end{array}$ & & & $\begin{array}{l}\text { - Mutila/neska: desberdintasunak. } \\
\text { - Aurpegiko atalak. } \\
\text { - Gorputz segmentuak: besoak, hankak. } \\
\text { - Elikagai motak. }\end{array}$ \\
\hline & $\begin{array}{l}\text { 2.unitatea: } \\
\text { Piramideko altxorra }\end{array}$ & & \multirow{3}{*}{2 urte } & $\begin{array}{l}\text { - Segmentuak eta artikulazioak. } \\
\text { - Bereizgarriak eta irudi orokorra. } \\
\text { - Zentzumenen organoak eta haien funtzioak. }\end{array}$ \\
\hline & $\begin{array}{c}\text { 6.unitatea: } \\
\text { Dinosaurioaren bila }\end{array}$ & & & - Zentzumenak erabiltzea: sentsazioak eta pertzepzioak \\
\hline & $\begin{array}{l}\text { 8.unitatea: } \\
\text { Uharte misteriotsua }\end{array}$ & & & $\begin{array}{l}\text { - Lanbideak lantzen dira. } \\
\text { - Emakume/gizonak irudietan identifikatzea lantzen da. }\end{array}$ \\
\hline & $\begin{array}{l}\text { 2.unitatea: } \\
\text { Hosto galduaren }\end{array}$ & & \multirow{3}{*}{3 urte } & $\begin{array}{l}\text { - Gorputza: zentzumenen elementuak eta organoak. } \\
\text { - Gorputzaren bereizgarriak: ilearen kolorea, sexua, tamaina... } \\
\text { - Zentzumenen organoen funtzioak. } \\
\text { - Sentsazioak: hotza/beroa. }\end{array}$ \\
\hline & $\begin{array}{l}\text { 3.unitatea: } \\
\text { Zaporeen festa }\end{array}$ & & & $\begin{array}{l}\text { - Emozioak eta sentimenduak. } \\
\text { - Gorputzaren oinarrizko beharrak: elikadura. }\end{array}$ \\
\hline & $\begin{array}{l}\text { 7. unitatea: } \\
\text { Botila batean bila mezua }\end{array}$ & & & $\begin{array}{l}\text { - Desberdintasunak errespetatzea. } \\
\text { - Norberaren gorputzarekiko espazioko erreferentziak. }\end{array}$ \\
\hline & $\begin{array}{l}\text { 2.unitatea: } \\
\text { Euriaren dantzan }\end{array}$ & & \multirow{2}{*}{4 urte } & $\begin{array}{l}\text { - Gorputz atal orokorrak lantzen dira (bekokia, masaila, kokotsa, } \\
\text { bekainak, eskuak, ezpainak, begiak, oinak). } \\
\text { - Zentzumenen organoak. }\end{array}$ \\
\hline & $\begin{array}{l}\text { 3.unitatea: } \\
\text { Illaren agurra }\end{array}$ & & & - Norberaren gorputza zaintzeko ohiturak: hortzak garbitzea. \\
\hline \multirow{4}{*}{ 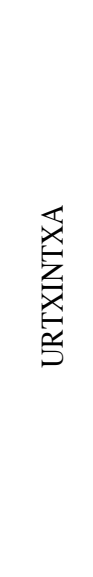 } & $\begin{array}{l}\text { 5. unitatea: } \\
\text { Negua (Hotzaz dar-dar) }\end{array}$ & \multirow{2}{*}{$\begin{array}{c}1998 \\
\text { eta } 2009\end{array}$} & \multirow[b]{2}{*}{3 urte } & $\begin{array}{l}\text { - Gorputzean hotza sentitzearen esperimentazioa. } \\
\text { - Zein arropa jarri hotza egiten duenean ikasi. }\end{array}$ \\
\hline & $\begin{array}{l}\text { 7. unitatea: } \\
\text { Gorputza eta jantziak (Hau da } \\
\text { nire gorputza polita benetan) }\end{array}$ & & & $\begin{array}{l}\text { - Nor naiz? Nolako naiz? Neska eta mutil lanketa. } \\
\text { - Gorputz atal orokorrak lantzen dira: Besoak, eskuak, hankak, oi- } \\
\text { nak, begia, sudurra, ahoa, aurpegia. }\end{array}$ \\
\hline & $\begin{array}{c}\text { 5. Unitatea: } \\
\text { Gorputza (Handitzen) }\end{array}$ & $\begin{array}{l}1998 \text { eta } \\
2010 \\
\text { urtekoak }\end{array}$ & 4 urte & $\begin{array}{l}\text { - Neska mutila ahal naiz? Hauxe gehiago lantzen da. } \\
\text { - Gorputza hazten doala lantzen da. } \\
\text { - Bakoitzaren gorputzak nolakoak diren aztertzen dute. } \\
\text { - Entzumenen eta emozioen lanketa egiten da. }\end{array}$ \\
\hline & $\begin{array}{c}\text { 7. Unitatea: } \\
\text { Gorputza (Horrelakoa naiz) }\end{array}$ & $\begin{array}{c}2000 \text { eta } \\
2009\end{array}$ & 5 urte & $\begin{array}{l}\text { - Haurra bat jaiotzeko prozesua lantzen da. } \\
\text { - Sentimenduak lantzen dira. } \\
\text { - Bakoitza nolakoa den lantzen da (adina, izenak, noiz jaio eta altuera). } \\
\text { - Gorputzaren barrualdearen lanketa (birikak, bihotza...). } \\
\text { - Ohitura egokiak lantzen dira. }\end{array}$ \\
\hline
\end{tabular}




\section{ERANSKINA}

\section{Elkarrizketak eta eztabaida-taldeak gidatzeko gidoia}

Gorputza

- Haur Hezkuntzako Curriculumeko helburuetako bat da: «Bere gorputza ezagutzeko, gorputzak ematen dituen aukerak zein diren eta desberdintasunak errespetatzen ikas dezan». Zer egiten duzue helburu hori lantzeko asmoz?

- Zer hitz erabiltzen dira gelan? Zeintzuk dakartzate etxetik?

- Nola lantzen duzue gorputza?

- Gorputz-atalak? Gorputza osotasunean?

- Nola erabiltzen da komuna ikaskuntza espazio bezala? Bestelako txoko berezirik erabiltzen da hori lantzeko?

- Noiz lantzen da? Urtean zehar?

- Zein material erabiltzen duzue gorputza lantzeko?

- Gai honen lanketa prestatzen duzuen bileretan, ikuspegi eta proposamen oso desberdinak agertzen dira?

- Hori guztia kontutan hartuta... Zein da gorputza lantzearen helburua? 